\title{
PELAKSANAAN PEMIDANAAN TERHADAP ANAK YANG BERHADAPAN DENGAN HUKUM (STUDI KASUS PUTUSAN PENGADILAN NEGERI CURUP NOMOR : 4/PID.SUS.AN/2015/PN.CRP)
}

\author{
Rachmat Saputra, SH \\ Dr. Yuherman, S.H., M.H., M.Kn \\ Fakultas Hukum Universitas Sahid Jakarta \\ ylo.lawoffice@gmail.com
}

\begin{abstract}
ABSTRAK
Pelaku tindak pidana tidak hanya dilakukan oleh orang dewasa, melainkan anak-anak juga dapat melakukan tindak pidana, di Indonesia tindak pidana yang dilakukan oleh anak cukup banyak yang salah satunya adalah kasus penyalahgunaan narkotika pada putusan Pengadilan Negeri Curup Nomor : 4/Pid.Sus.AN/2015/PN.CRP dimana peneliti merumuskan masalah, 1) bagaimana pertimbangan hakim dalam penjatuhan pidana terhadap anak ditinjau dari sistem peradilan pidana anak pada putusan Pengadilan Negeri Curup Nomor : 4/Pid.Sus.AN/2015.PN.CRP dan 2) apakah vonis pidana terhadap anak pada putusan Pengadilan Negeri Curup Nomor : 4/Pid.Sus.AN/2015.PN.CRP sudah sesuai dengan tujuan sistem pemidanaan anak. Penelitian ini menggunakan metode penelitian hukum normatif, Merupakan studi kepustakaan dengan analisis kualitatif

Kata kunci Kejahatan, Narkotika, Pemidanaan Anak
\end{abstract}

\begin{abstract}
Perpetrators of criminal acts are not only committed by adults, but children can also commit criminal acts, in Indonesia there are quite a lot of crimes committed by children, one of which is the case of narcotics abuse in the Curup District Court decision Number: 4 / Pid.Sus AN / 2015 / PN.CRP where the researcher formulated the problem, 1) how the judge's consideration in imposing crimes against children in terms of the juvenile criminal justice system in the Curup District Court decision Number: 4 / Pid.Sus.AN / 2015.PN.CRP and 2 ) whether the criminal verdict against children in the decision of the Curup District Court Number: 4 / Pid.Sus.AN / 2015.PN.CRP is in accordance with the objectives of the child penal system. This research uses normative legal research methods, is
\end{abstract}


a literature study with qualitative analysis Keywords Crime, Narcotics, Child Crime

\section{A. PENDAHULUAN}

Pelaku tindak pidana tidak hanya dilakukan oleh orang dewasa, melainkan anak-anak juga dapat melakukan tindak pidana. Mengenai pengertian anak yang melakukan tindak pidana atau yang berkonflik dengan hukum diatur dalam Undang-Undang Nomor 11 Tahun 2012 tentang Sistem Peradilan Pidana Anak. Sistem Peradilan Pidana Anak juga dikenal adanya pembatasan umur untuk anak dapat diadili pada sidang anak. Menurut ketentuan Pasal 1 angka 3 UndangUndang Nomor 11 Tahun 2012 tentang Sistem Peradilan Pidana Anak, bahwa anak yang dapat diadili dalam sidang anak yaitu anak yang telah berumur minimal 12 (dua belas) tahun dan maksimal 18 (delapan belas) tahun

Anak sebagai bagian dari bangsa Indonesia, yang juga merupakan generasi penerus bangsa memiliki hak konstitusional untuk mendapatkan perlindungan oleh Negara. Perlindungan Negara terhadap hak anak dalam konstitusi negara ini ditegaskan dalam Pasal 28B ayat (2) Undang-Undang Dasar Negara Republik Indonesia 1945, yaitu yang berbunyi, "Setiap anak berhak atas kelangsungan hidup, tumbuh dan berkembang serta berhak atas perlindungan dari kekerasan dan diskriminasi”.

Dalam berbagai hal upaya pembinaan dan perlindungan tersebut, dihadapkan pada permasalahan dan tantangan dalam masyarakat dan kadangkadang dijumpai penyimpangan perilaku dikalangan anak, bahkan lebih dari itu terdapat anak yang melakukan perbuatan melanggar hukum, tanpa mengenal status sosial dan ekonomi. Disamping itu, terdapat pula anak, yang karena satu dan lain hal tidak mempunyai kesempatan memperoleh perhatian baik secara fisik, mental, maupun sosial. Karena keadaan diri yang tidak memadai tersebut, maka baik sengaja maupun tidak sengaja sering juga anak melakukan tindakan atau berperilaku yang dapat merugikan dirinya dan atau masyarakat.

Kenakalan remaja berarti hal-hal yang berbeda dalam golongan yang sama pada waktu-waktu yang berbeda, dalam penggunaan yang popular, pengertian kenakalan remaja digunakan digunakan untuk melukiskan sejumlah besar tingkah laku anak-anak dan remaja yang tidak baik atau yang tidak disetujui. Dalam pengertian ini hampir segala sesuatu yang dilakukan oleh remaja yang tidak disukai oleh orang lain disebut kenakalan remaja ${ }^{1}$

Hubungan antara orang tua dengan anaknya merupakan suatu hubungan yang hakiki, baik hubungan psikologis maupun mental spiritualnya. Mengingat ciri dan sifat anak yang khas tersebut, maka dalam menjatuhkan pidana atau tindakan

\footnotetext{
${ }^{1}$ Sri Widoyati Wiratmo Soekito, Anak Dan Wanita Dalam Hukum, Jakarta : LP3ES, 1989, hlm 1
} 
terhadap anak nakal diusahakan agar anak dimaksud jangan dipisahkan dari orang tuanya. Apabila karena hubungan antara orang tua dan anak kurang baik, atau karena sifat perbuatannya sangat merugikan masyarakat sehingga perlu

memisahkan anak dari orang tuanya, hendaklah tetap dipertimbangkan bahwa pemisahan tersebut semata-mata demi pertumbuhan dan perkembangan anak secara sehat dan wajar.

Di samping pertimbangan tersebut di atas, demi pertumbuhan dan perkembangan mental anak, perlu ditentukan pembedaan perlakuan di dalam hukum acara dan ancaman pidananya. Kriminalitas atau kejahatan itu bukan merupakan peristiwa herediter (bawaan sejak lahir, warisan) juga bukan merupakan warisan biologis.5 Bahkan tindakan penyimpangan tersebut sudah termasuk sebagai tindak kriminal dan bukan lagi sebagai kenakalan anak. Sebagaimana disebutkan pada Undang Undang Nomor 23 Tahun 2002 Tentang Perlindungan Anak Pasal 16 bahwa anak yang berkonflik dengan hukum berhak memperoleh perlindungan dari sasaran penganiayaan, penyiksaan, atau penjatuhan hukuman yang tidak manusiawi, berhak untuk memperoleh kebebasan sesuai dengan hukum, penangkapan, penahanan, atau tindak pidana penjara anak hanya dilakukan apabila sesuai dengan hukum yang berlaku dan hanya dapat dilakukan sebagai upaya terakhir.

Sebagaimana peristiwa yang terjadi pada putusan Pengadilan Negeri Curup Nomor : 4/Pid.Sus.AN/2015.PN.CRP dimana terdakwa febri wijaya als uda bin firman arianja bersama dengan saksi waras santoso berangkat dari Desa Tabarnah Kec. Curup Utara Kab.Rejang Lebong dengan mengunakan 1(satu) unit sepeda motor menuju Desa Apur Kec. Sindang Beliti Ulu Kab. Rejang lebong untuk membeli ganja seharga Rp.100.000,- (seratus ribu rupiah) kepada sdr Mojes (DPO), sampai di Simpang Apur saksi Waras menyuruh terdakwa menunggu sedangkan saksi waras dengan menggunakan sepeda motor langsung menuju desa apur untuk membeli narkotika Golongan I dalam bentuk tanaman jenis ganja. Tidak lama kemudian saksi waras langsung menjemput terdakwa dan mengatakan "Ganja uda di dapatkan" selanjutnya Terdakwa mengendarai sepeda motor tersebut bersama dengan saksi waras langsung pulang menuju Curup dan saat melintasi jalan umum Kel. Air Duku sepeda motor yang di kendarai oleh terdakwa bersama saksi waras di berhentikan oleh saksi Udi Handoko berserta anggota Polsek Curup yang telah mendapat informasi dari masyarakat bahwa terdakwa bersama saksi waras memiliki narkotika golongan i jenis ganja dan pada saat sepeda motor di berhentikan saksi waras langsung meloncat dari sepeda motor yang di kendarai terdakwa dan langsung melarikan diri yang langsung dikejar oleh 
sebagian polisi berpakaian preman, karena melihat hal tersebut terdakwa langsung berusaha melarikan diri dengan mengendarai sepeda motor yang ia kendarai dan terdakwa berhasil di amankan di jalan Umum Kel. Talang ulu oleh saksi Udi Handoko berserta anggota Polsek Curup

Setelah ditangkap dan di proses hukum bahwa anak tersebut diputus oleh Pengadilan Negeri Curup dengan hukuman penjara selama 2 (dua) tahun, dimana jika menggunakan teori Kepastian Hukum bahwa anak tersebut memang benar telah memiliki tanpa hak narkotika jenis ganja sehingga dihukum penjara, namum jika dikaitkan dengan Azas kemanfaatan apakah telah sesuai bahwa anak yang notabene diajak oleh orang dewasa membeli narkotika kemudian tertangkap, bermanfaatkah dihukum penjara selama 2 (dua) tahun tersebut, juga jika dikaitkan dengan teori keadilan apakah adil anak tersebut dihukum penjara dimana anak tersebut tidak mengetahui bahwa diajak membeli narkotika jenis ganja.

\section{B. METODE PENELITIAN}

Metode penelitian yang digunakan dalam penelitian ini didasarkan pada metode penelitian hukum normatif merupakan penelitian kepustakaan, yaitu penelitian terhadap data sekunder. Penelitian hukum dilakukan dengan cara meneliti bahan pustaka atau data sekunder belaka dapat dinamakan penelitian hukum normatif atau penelitian kepustakaan kualitatif.

\section{HASIL PENELITIAN DAN PEMBAHASAN Pertimbangan hakim dalam penjatuhan pidana terhadap anak ditinjau dari sistem peradilan pidana anak pada putusan Pengadilan Negeri Curup Nomor : 4/Pid.Sus.AN/2015.PN.CRP}

Ditinjau dari Asas Keadilan bahwa tidak adil anak-anak yang masih memiliki catatan baik sebelumnya dan diajak oleh orang lain tanpa sepengetahuan nya terlebih dahulu ternyata akan melakukan pembelian narkotika jenis ganja untuk dijual kembali dan kemudian tertangkap dan anak tersebut tidak berusaha melarikan diri ketika dihadang oleh polisi ketika sedang mengendarai motor, hal tersebut berbeda dengan yang dilakukan oleh saksi waras dimana langsung loncat dari motor dan mencoba melarikan diri, dimana barang narkotika jenis ganja tersebut dipegang atau dikuasai oleh saksi waras.

Kepastian hukum sebagai perlindungan yustiable terhadap tindakan sewenang-wenang yang berarti bahwa seseorang akan dapat memperoleh sesuatu yang diharapkan dalam keadaan tertentu. Masyarakat mengharapkan adanya kepastian hukum, karena dengan adanya kepastian hukum masyarakat akan lebih tertib. Hukum bertugas menciptakan kepastian hokum karena bertujuan ketertiban masyarakat. Radbruch memberi pendapat yang cukup mendasar mengenai kepastian hukum, ada empat hal yang berhubungan dengan makna kepastian 
hukum. Pertama bahwa hukum itu positif. Kedua, bahwa hukum itu didasarkan pada fakta atau hukum yang ditetapkan itu pasti yaitu dengan adanya keterangan. Ketiga, bahwa kenyataan (fakta) harus dirumuskan dengan cara yang jelas sehingga menghindari kekeliruan dalam pemaknaan di samping mudah dilaksanakan. Keempat, hukum positif tidak boleh mudah berubah.

Jadi pada intinya adalah hakim dalam menjatuhkan putusan selain berdasar 
pada fakta yang terjadi juga harus memperhatikan dasar hukum yang menjadi dasar putusannya tersebut yaitu mengacu pada peraturan perundangundangan yang berlaku apakah telah sesuai atau belum. Karena masyarakat mengharapkan kepastian hukumnya agar mengerti peraturannya dan mengerti apa yang diperbuatnya sehingga tujuan daripada hukum untuk menciptakan ketertiban dan kedamaian akan tercapai. Sebagaimana penulis berpendapat bahwa putusan hakim yang menyatakan bahwa terdakwa melakukan "Permufakatan Jahat Membeli Narkotika Golongan I Bentuk Tanaman" dimana menurut pengertian Pasal 1 Angka 18 Undang Undang Nomor 35 Tahun 2009 tentang Narkotika yang dimaksud dengan pemufakatan jahat adalah perbuatan dua orang atau lebih yang bersekongkol atau bersepakat untuk melakukan, melaksanakan, membantu, turut serta melakukan, menyuruh, menganjurkan, memfasilitasi, memberikan konsultasi, menjadi anggota suatu organisasi Narkotika atau mengorganisasikan suatu tindak pidana Narkotika tidaklah sesuai dengan kenyataan bahwa terdakwa diajak. pengalaman penanganan anak yang diduga melakukan tindak pidana yang dilakukan oleh Lembaga Advokasi Hak Anak (LAHA) yang berkedudukan di Bandung, ternyata $95 \%$ anak dikenakan penahanan dan $100 \%$ vonis hakim berupa pidana penjara. Banyaknya anak anak yang masuk tahanan dan/atau divonis hakim untuk masuk penjara di samping dapat menimbulkan dampak frustasi pada si anak juga dapat menimbulkan masalah berat kelak di kemudian hari dan dapat menimbulkan faktor kriminogen ${ }^{2}$

Selain itu penjatuhan pidana dimaksudkan agar terdakwa tidak mengulangi perbuatan tersebut dan juga bagi masyarakat merupakan suatu shock therapy. Sekali lagi penjatuhan pidana bukan semata-mata sebagai pembalasan dendam tetapi yang paling penting adalah pemberian bimbingan dan pengayoman bagi anak.

Pada kasus ini terdakwa bukanlah pengedar atau rencana mengedarkan, juga bukanlah pemakai narkotika jenis ganja yang menjadi barang bukti, juga anak tersebut hanya diajak oleh saksi waras. Sehingga menurut penulis penjatuhan hukuman kepada terdakwa malah akan membuat anak tersebut semakin terjerat di lingkaran penjahat narkotika karena dijebloskan ke penjara, padahal sebelumnya anak tersebut adalah anak baik-baik sebagaimana diungkapkan oleh ibu terdakwa.

\footnotetext{
2 utedjo, W., \& Melani, "Hukum pidana anak edisi revisi". Cetakan ke 4, Bandung : PT Refika Aditama, 2013, hlm 132
} 


\section{Vonis pidana terhadap anak pada putusan Pengadilan Negeri Curup Nomor : 4/Pid.Sus.AN/2015.PN.CRP ditinjau dari tujuan pemidanaan anak}

Masih adanya putusan pengadilan anak, yang memberikan pidana penjara terhadap anak berhadapan hukum, dari pada sebuah tindakan yang

mengedepankan hak anak, sebenarnya tidak sesuai dengan filosofi dari pemidanaan dalam hukum pidana anak. Penjatuhan pidana secara tidak tepat dapat mengabaikan pengaturan perlindungan, karena pemidanaan anak seharusnya adalah jalan keluar terakhir (ultimum remedium / the last resort principle) dan dijatuhkannya hanya untuk waktu yang singkat, dalam hukum dikenal istilah "ultimum remidium" yang mempunyai makna bahwa sanksi pidana dipergunakan manakala sanksi-sanksi yang lain sudah tidak berdaya, sanksi pamungkas (terakhir). Dimaknakan bahwa dalam sanksi pidana suatu undang-undang sebagai sanksi terakhir, setelah sanksi perdata, maupun sanksi administratif, ${ }^{3}$ sedangkan Dalam konsep hukum progresif manusia berada di atas hukum, hukum hanya menjadi sarana untuk menjamin dan menjaga berbagai kebutuhan manusia. Hukum tidak lagi dipandang sebagai suatu dokumen yang absolute dan ada secara otonom

Hukuman yang terbaik bagi anak dalam peradilan pidana bukan hukuman penjara, melainkan tindakan ganti rugi menurut tingkat keseriusan tindak pidananya, Ganti Rugi yang dimaksud adalah sebuah sanksi yang diberikan oleh sistem peradilan pidana/pengadilan yang mengharuskan pelaku membayar sejumlah uang atau kerja, baik langsung maupun pengganti. ${ }^{4}$

Hukuman yang terbaik bagi anak dalam peradilan pidana bukan hukuman penjara, melainkan tindakan ganti rugi menurut tingkat keseriusan tindak pidananya, Ganti Rugi yang dimaksud adalah sebuah sanksi yang diberikan oleh sistem peradilan pidana/pengadilan yang mengharuskan pelaku membayar sejumlah uang atau kerja, baik langsung maupun pengganti. ${ }^{5}$

Diversi untuk mewujudkan Pendekatan Keadilan Restoratif wajib diutamakan dalam Sistem Peradilan Pidana Anak. Pada tingkat penyidikan di Kepolisian, tingkat penuntutan di Kejaksaan, dan tingkat pemeriksaan di

\footnotetext{
${ }^{3}$ Hadi Supeno, "Kriminalisasi Anak", Jakarta : PT Gramedia Pustaka Utama, 2010, hlm 53

${ }^{4}$ Hukuman yang terbaik bagi anak dalam peradilan pidana bukan hukuman penjara, melainkan tindakan ganti rugi menurut tingkat keseriusan tindak pidananya, Ganti Rugi yang dimaksud adalah sebuah sanksi yang diberikan oleh sistem peradilan pidana/pengadilan yang mengharuskan pelaku membayar sejumlah uang atau kerja, baik langsung maupun pengganti.

5 Emy Rosna Wati, "Penanganan Anak Yang Berkonflik Dengan Hukum," Justitia Jurnal Hukum, Vol.1, No.2, (Oktober 2017) : 285
} 
pengadilan negeri, perkara anak yang diancam dengan pidana penjara dibawah 7 (tujuh) tahun dan bukan pengulangan pidana wajib dilakukan Diversi, dengan tujuan tercapainya perdamaian korban dengan pelaku (anak), Menghindarkan Anak dari perampasan kemerdekaan, Penyelesaiaan perkara Anak diluar peradilan, Mendorong masyarakat berpartisipasi dan Menumbuhkan rasa tanggung jawab terhadap anak hasil kesepakatan Diversi dapat berbentuk perdamaian dengan atau tanpa ganti kerugian terhadap korban, pelaku anak disertakan dalam pendidikan

atau pelatihan pada lembaga pendidikan pada Lembaga Penyelenggaraan Kesejahteraan Sosial (LPKS) selama 3 (tiga) bulan, atau pelayanan terhadap masyarakat

Kasus kasus anak yang dibawa dalam proses peradilan adalah kasus kasus yang serius saja, itu juga harus selalu mengutamakan prinsip kepentingan terbaik bagi anak, serta proses penghukuman adalah jalan terakhir (Ultimum Remedium) dengan tetap tidak mengabaikan hak hak anak. Diluar itu kasus kasus anak dapat diselesaikan melalui mekanisme non formal yang didasarkan pada pedoman yang baku. Bentuk penanganan non formal dapat dilakukan dengan diversi sebagaimana proses mediasi yang difasilitasi oleh penegak hukum pada setiap tingkat untuk mencapai keadilan restoratif yang dapat diselesaikan dengan mewajibkan anak yang berhadapan dengan hukum untuk mengikuti pendidikan atau pelatihan pada lembaga tertentu seperti berupa tindakan lainnya yang dilakukan dengan pemulihan bagi anak serta korban, ataupun jika terpaksa terjadi penghukuman hak hak anak tidak boleh diabaikan. Sehingga pada akhirnya penanganan nonformal dapat terlaksana dengan baik jika diimbangi dengan upaya menciptakan sistem peradilan yang kondusif.

Keputusan hakim dengan menjatuhkan hukuman kurungan penjara selama 2 (dua) tahun tidaklah tepat karena menurut Undang Undang Nomor 11 Tahun 2012 tentang Sistem Peradilan Pidana Anak hakim masih memiliki pilihan lain dengan mengedepankan keadilan restoratif yaitu dapat melakukan diversi pada kasus ini sehingga dimana anak yang notabene bukanlah pengguna maupun pengedar narkoba dapat dibina dengan sesuai dan benar agar tidak kembali terjerat masalah serupa.

\section{PENUTUP}

a. Kesimpulan

Berdasarkan hasil penelitian dan pembahasan diatas, maka penulis berkesimpulan bahwa: 
1. Pertimbangan hakim pada kasus ini tidaklah tepat, dimana pada fakta materiil kasus ini terdakwa bukanlah pengedar atau yang memiliki rencana mengedarkan. Terdakwa juga bukanlah pemakai narkotika jenis ganja yang menjadi barang bukti, terdakwa hanya diajak oleh saksi waras kemudian di iming-imingi diberikan bagian dari narkotika tersebut. Sehingga menurut penulis penjatuhan hukuman penjara kepada terdakwa tidaklah bermanfaat, padahal anak tersebut adalah anak baik-baik sebagaimana diungkapkan oleh ibu terdakwa.

2. Vonis hakim untuk kurungan penjara selama 2 (dua) tahun tidaklah tepat, ditinjau dari Undang-Undang Nomor 11 Tahun 2012 tentang Sistem Peradilan Pidana Anak, karena hakim harus mengupayakan keadilan restoratif pada kasus pidana yang menimpa anak-anak, yang mana pada fakta persidangan tidak ditemukan upaya hakim untuk melakukan diversi dalam menangani kasus ini atau dengan kata lain tidak ada upaya hakim untuk menjalankan sistem peradilan pidana anak yang sesuai dengan amanah Undang-Undang

b. Adapun saran yang dapat diberikan dari kesimpulan ini adalah :

1. Kepada para Hakim haruslah mempertimbangkan masa depan anak dalam menjatuhkan hukuman kepada anak, dan kepada Pemerintah haruslah memberikan sosialisasi yang dilakukan secara terus menerus dan berkesinambungan ke sekolah - sekolah mulai dari tingkat sekolah dasar sampai dengan perguruan tinggi tentang bahaya serta dampak narkotika yang dapat merusak kehidupan bangsa dengan menanamkan nilai - nilai agama dan nilai sosial di masyarakat luas guna memerangi narkotika tersebut. Agar tidak ada lagi anak-anak yang terseret kasus - kasus narkotika.

2. Kepada Mahkamah Agung agar dapat memberikan sanksi administratif yang tegas kepada Hakim yang terbukti tidak menjalankan praktek keadilan restoratif terhadap kasus-kasus yang menimpa anak-anak, sehingga pelaksanaan praktek keadilan restoratif pada kasus-kasus yang menimpa anak-anak dapat dilaksanakan sebagaimana mestinya supaya tujuan sistem peradilan pidana anak bisa tercapai..

\section{DAFTAR PUSTAKA Buku}

A Madjedi Hasan, Kontrak Minyak dan Gas Bumi Berazas Keadilan dan Kepastian Hukum, Jakarta : Fikahati Aneska, 2009. 
Adami Chazawi, Pelajaran Hukum Pidana Bagian I (Stelsel Pidana. Tindak pidana. Teori Teori Pemidanaan, dan Batas Berlakunya Hukum Pidana). Cet. 1., Jakarta : PT Raja Grafindo Persada, 2002. .

Andi Hamzah, Asas-Asas Hukum Pidana, Jakarta : Rinneka Cipta, 1994.

B. Simanjuntak, Kriminologi, Bandung : Tarsito, 1984.

Bambang Waluyo, Pidana dan Pemidanaan, Jakarta : Sinar Grafika, 2004.

Beniharmoni Harefa dan Vivi Ariyanti, Seputar Perkembangan Sistem Peradilan Pidana Anak dan Tindak Pidana Narkotika di Indonesia, Yogyakarta : Deepublish, 2016.

Jimly Asshiddiqie, Teori Hans Kelsen Tentang Hukum, Konstutusi Press (konpres), Jakarta, 2012.

Kartini kartono, Patologi Sosial, Jakarta : PT RajaWali pres, 2009.

Laurensius Arliman S, Perlindungan Anak, Yogyakarta : Deepublish, 2016.

Maidin Gultom, Perlindungan Hukum Terhadap Anak Dan Perempuan, Bandung : PT Refika Aditama, 2012.

Maidin Gultom, Perlindungan Hukum terhadap Anak dalam Sistem Peradilan Pidana Anak di Indonesia, Bandung : Refika Aditama, 2008.

Nandang Sambas, Pembaruan Sistem Pemidanaan Anak di Indonesia, Yogyakarta : Graha Ilmu, 2010.

P.A.F. Lamintang dan Fransciscus Theojunior Lamintang, Dasar-Dasar Hukum Pidana Di Indonesia. Jakarta : Sinar Grafika, 2014.

Sri Sutatiek, Hukum Pidana Anak Di Indonesia, Yogyakarta : Aswaja Pressindo, 2015.

Sudarsono, Pengantar Ilmu Hukum, Cet ke 5, Jakarta : PT Rineka Cipta, 2007

Sudikno Mertokusumo, Penemuan Hukum Sebuah Pengantar, Yogyakarta : Liberty, 2001.

\section{Jurnal}

Dian Ety Mayasari, “Perlindungan Hak Anak Kategori Juvenile Delinquency Children's Rights 
Protection In The Juvenile Delinquency Category, ” Kanun Jurnal Ilmu Hukum, Vol. 20, No.3, 2018

Emy Rosna Wati, “Penanganan Anak Yang Berkonflik Dengan Hukum,” Justitia Jurnal Hukum, Vol.1, No.2, 2017

Guntarto Widodo, "Sistem Pemidanaan Anak Sebagai Pelaku Tindak Pidana Perspektif

Undang-Undang Nomor 11 Tahun 2012 Tentang Sistem Peradilan Pidana Anak, J Jurnal Surya Kencana Dua : Dinamika Masalah Hukum dan Keadilan, Vol.6, no.1, 2016

Setya Wahyudi, "Penegakan Peradilan Pidana Anak Dengan Pendekatan Hukum Progresif

Dalam Rangka Perlindungan Anak, ” Jurnal Dinamika Hukum, Vol. 9 No.1, 2009

Sulardi dan Yohana Puspitasari Wardoyo, “Kepastian Hukum, Kemanfaatan, Dan

Keadilan Terhadap Perkara Pidana Anak, ” Jurnal Yudisial Vol.8, No.3, 2015

Fence M. Wantu, “Mewujukan Kepastian Hukum, Keadilan dan Kemanfaatan

Dalam Putusan Hakim di Peradilan Perdata," Jurnal Dinamika Hukum, Vol.12, No.3, 2012

\section{Perundang - Undangan}

Indonesia, Undang-Undang Nomor 1 tahun 1946 tentang Peraturan Hukum Pidana / Kitab Undang-Undang Hukum Pidana (KUHP)

Indonesia, Undang-Undang Nomor 35 Tahun 2014 Tentang Perubahan Atas Undang-Undang Nomor 23 Tahun 2002 Tentang Perlindungan Anak.

Indonesia, Undang-Undang Nomor 11 Tahun 2012 tentang Sistem Peradilan Pidana Anak

Indonesia, Undang-Undang Nomor 2 Tahun 2002 tentang Kepolisian Negara Republik Indonesia.

Indonesia, Undang-Undang Nomor 35 Tahun 2009 tentang Narkotika 